\title{
Towards Effective Use of ICTS and Traditional Media for Sustainable Rural Transformation in Africa
}

\author{
Akpomuvie, Orhioghene, Benedict \\ Delta State University, Sociology Department, P.M.B. 1, Abraka, Delta State, Nigeria \\ E-mail:bakpomuvie@gmail.com
}

\begin{abstract}
Development programmes initiated by governments in parts of Africa aimed at improving the living standard of the people, have either achieved minimal success or failed because of the negative attitude of the people. One issue that has therefore dominated discussions among development agencies and initiators in Africa is that of dealing with the people's attitudes and responses to issues of development. This paper is therefore geared towards exploring ways in which ICTs and traditional media could become effective tools in the campaigns and mobilization for the adoption of innovations, which is central to rural development in Africa. The method of content analysis using review of existing document such as books, journals, periodicals, case record and others documented by government, individuals and organization s was utilized. The findings revealed that the majority of the people in Africa lived in the rural areas and were not abreast with information about government programmes aimed at improving them. Apart from acknowledging the basic challenges confronting policy makers, development communicators and other stakeholders in the development process, the paper recommends among others, that governments in Africa should create the enabling environment for the ICTS to be effectively used and synergized with traditional media in achieving development communication goals at all levels.
\end{abstract}

Keywords: Attitudes, Access, Development programmes, Mobilization, Innovations, Rural, Communication, Synergy etc.

\section{Introduction}

Rural development can be viewed as the development of the moral, social, political and economic potentials of rural communities to enhance their economic self-reliance through the provision of appropriate infrastructure such as pipe-borne water, electricity, roads, health care and so on.

According to Muoghalu (1992), rural development in Africa has become more urgent and important today than ever before. Its relevance has an economic and welfare content. Economically, as the debt burden of developing countries mount and their foreign exchange receipts diminish, there is the need to be increasingly more self-reliant not only in food and industrial raw materials supply, but also to increase the content, structure and volume of the export sector. Its urgency derives from the need to correct or minimize the problems created by unprecedented high rate of urbanization including rural - urban migration, shortfall in the provision of urban services and amenities, combating urban crimes, resuscitation of declining rural economy and creation of employment opportunities.

One of the issues that have dominated discussions among development agencies and initiators in Africa is that of dealing with people's attitudes and responses to issues of development. This according to Ochonogor (2005) is based on the observation that many development programmes initiated by governments in parts of Africa, aimed at improving the living standard of the people have either achieved minimal success or failed because of the negative attitude of the people. An attitude formed in part by the low-level of information available to them about the programmes.

Although the people are capable of interpreting and understanding development - oriented messages and taking decisions on them, they have often times been kept in the dark or mis-informed about vital development projects that required their co-operation and participation to succeed. Hence Barghouti remarked that:

the political priorities of many governments in developing countries, which commonly own most of the mass media, do not allow ample time and space in the media to improve the people's understanding of their problems in agriculture, health and nutrition.

Perhaps, this explains why in Africa, many people participate in programmes because they have been asked to, not because they understand the very essence of the programmes.

The majority of the populations of countries in Africa live in the rural areas and the most effective way to keep them abreast with the programmes of governments is to popularize them at the grassroots through ICTS and the traditional media. Agbodike (1992) observed that ICTS and particularly the traditional media has to play this role of influencing development by providing the people with necessary information and required skills to overcome the present economic imbroglio in Africa. For example in Northern Nigeria, radio and television which are ICTS have been the major means of ICTS contributions to rural development in that part of the country. The National Agricultural Extension Laison Services (NAERLS) Zaria, has been disseminating proven relevant agricultural information to farmers through the radio and television. Through these media, new agricultural findings are broadcast to the rural farmers in traditional languages such as; Nupe, Hausa, Fufulde, Kanuri and so on. 
The past mobilization campaigns aimed at inculcating in the people a sense of national direction for meaningful development, especially for the rural masses of the country has failed because their messages were mainly directed to the urban dwellers that constitute less than 40 per cent of the population. The majority of the people who lived in the rural areas were either forgotten by deliberate omission or not reached due to wrong choices of channels of communication. It is an undisputable fact that the government has indicated its readiness to develop the rural areas and improve the quality of life of the rural dwellers. But unfortunately, political activitists, government officials and agencies charged to execute this assignment are urban dwellers and so have no intimate knowledge of the problems of the rural dwellers. They also have the erroneous conception that all Nigerians have access to the mass media and so used them to the total exclusion of the traditional media which the majority of Nigerians depend on for their information. They forget that, for instance, out of the 97,000 identified communities in Nigeria today, less than 300 are penetrated by any particular newspaper on a daily basis. Many of the rural dwellers do not own a radio. And in an environment devoid of electricity and marked by abject poverty, television viewing becomes a luxury and is generally non-existent.

Even for those in the urban areas, who have heard and read about these mobilization campaigns, the programmes were often times seen as those of the government and not their own and so were completely alienated from them. The cumulative effect of these factors and circumstances was that the masses failed to be effectively mobilized, the campaigns failed to make the required total impact on the masses and the problems of the latter, particularly in respect of those in the rural areas remained with them.

To the ideologists; the past mobilization campaigns did not make sustained impact on the people because they failed to inculcate in the people the laudable values proclaimed by them because they lacked ideological direction .... and could not answer in a non-tautological fashion the crucial question. For what? and for whom?

The main thrust of the argument here is that the bureaucrats and majority of the rural dwellers belong to different social classes and their interests are not identical. Measures to fully involve the rural people in their own development and to aim at an equitable distribution of the national output had, hitherto, not been seriously considered. Having rendered the masses irrelevant, the process excluded the possibility of mobilizing them and releasing their energies for development. This had, perhaps, been the greatest setback to rural development; the fact that circumstances did not permit the tapping of the most valuable resources of the country, the energy of its people (Idode, 1989). All the talk about mobilization of the peasantry and of primary emphasis on the development of the rural areas, where most of our people lived "failed to produce the desired results".

It was mainly because the wrong approach was adopted in solving the problems of rural development. Instead of tapping the vast resources which the full and effective participation of the people would have provided, theses resources were neglected in favour of bureaucratic inputs. The mobilization approach to rural development should recognize the people as worthy partners in the development process. Where they become part of the decision-making process, they would be committed towards ensuring that such decisions are fully executed. In addition, mobilization approach should also enable the government to easily elicit the support of the people in rural development efforts. Moreover, where the people's participation yield fruitful results, they would be encouraged to contribute more to ensure further success of their collective endeavours.

It is against this background that the paper explores ways in which ICTS and traditional media could be employed as effective tools in the campaigns and mobilization for the adoption of innovations, which is central to rural development particularly in Africa. The paper is also geared towards providing suggestions to aid policy formulators and development facilitators on how best to employ information to achieve the objectives of development programmes in Africa.

\section{Traditional Media and Communication}

Certain agencies such as age grades, village assembly and so on are basic in the evolution of human society and become overtly visible as soon as society takes shape. These agencies are therefore, referred to as traditional agencies because they are fundamental to the existence of man. Akude (1992) noted that in Nigeria and in most parts of Africa, such social groups characterize the rural communities and have in recent times mobilized themselves to form larger town unions.

There are development agents such as: corporate organizations, government and non-governmental organisations in Africa that are willing to bring social, economic, political and educational change to the rural dwellers. How can these agents pass the message of development across to the people? What methods can be utilized to re-orientate these rural dwellers? How can the rural poor be persuaded to adopted innovations such as mechanized farming instead of the use of cutlasses, hoes and shovels for farming? The answers to the above questions, point to one direction and that is traditional media and communication.

The traditional media are communication channels which reflect a people's culture. These media were not introduced to the people like the modern mass media but are part of the people's culture and contribute greatly in shaping their existence. As Nwabueze (1995) rightly observed, these media have been described as a continuous process of information dissemination, entertainment and education used in societies which have not been seriously dislocated by western culture or any other external influences. The people still depend on these media in parts of 
Africa because of their effective interpersonal nature. Similarly, Akpoveta (2006) conceptualized traditional media to include aspects of traditional African communication namely: folklore, music, town/village crier, village square meetings, age groups, festivals...

The channels of traditional communication in most African societies include: the market place, town crier, Age-grade organizations, traditional leaders, village square, drama, music, local churches, village conferences etc. In virtually all rural areas, there are "markets" and certain days are observed for their operation. As people engage in buying and selling, they interact and in the process, information are disseminated and feed backs are received immediately in some cases. The "town crier" moves round the community with a metal gong and wood to draw the attention of members to vital information or to an impending meeting of the members of the community. "Age-grade" is another channel common in the rural areas. Over the years, age grades in different communities have distinguished themselves in performing such roles aimed at enhancing the socio-economic life of the people. They perform such traditional functions as maintenance of law and order, settlement of disputes, information dissemination and mobilization of members towards development activities.

In rural communities there are those saddled with the responsibility of "leadership" and are expected to provide information to members as the case arises. In-fact, information from these leaders are often respected and accepted by villages. The "village square" is a meeting ground for members of the community and serves as relaxation spot after the day's work. As they interact, topical issues are discussed and information vital to their well being are shared and passed on to the entire community.

\section{Information and Communication Technologies (ICTs): Meaning and Communication Imperatives for Rural Development in Africa.}

The importance man attaches to communication has perhaps motivated him to invent different technologies to perfect communication both at the interpersonal and mass communication level. The invention of technology for distance communication began in 1830 with the development of the telegraph in England and the United States of America respectively. However in 1897, Guglielmo Marconi patented the wireless telegraph and by 1935, the first telephone call was made around the world. Another great improvement was witnessed in 1983 with the invention of the mobile cellular phone.

Information and Communication Technologies (ICTs), New Information and Communication Technologies (NICTs) or New Communication Technologies (NCTs) as they are variously referred to, are simply communication gadgets, hardware, equipment or facilities that have modernized, improved and eased exchange of ideas and information of various kinds between and among people within or across distant boundaries/frontiers. Nwodu (2003) describes ICTs as a generic name used to refer to a number of communication hardware adopted in ensuring instant dissemination of information and social values across the globe. ICT is the product of the convergence of digital technologies encompassing computers, telecommunications, audio-video and publishing. It covers mobile phones, personal computers, the internet, email, imaging technology, digital broadcasts and even cable television. ICT type range from web-enabled, network and stand-alone technologies.

Flor (2002) noted that ICT facilitates two elements critical in the Research-Extension-Farmer-Market Interface and technology transfer process: information access and networking. The storage and retrieval of research results facilitate information access while telecommunications facilitate networking. In both elements, several strategies and approaches have been employed. Among these strategies are: riding the tide of popular media; community-based-participatory media; capacity building of support agencies; knowledge management and employing a programmatic approach to ICT undertakings. Technology transfer modalities include: conventional and digital broadcasting; comic books; the use of low-end ICT; geographic information system or GIS and knowledge networks that tap a wide range of ICT products ranging from multimedia CDROMS to web-based services. (Yarhere, 2007).

The existing development assistance environment is most favourable for tapping information and communication technology for rural development and technology transfer. The Okinawa Summit of G7/G8 nations has established the primacy of bridging the Digital Divide in the international development assistance agenda. The World Bank has maintained its Information Development Grants Program while the European Community has established its own IT fund for "A user-friendly information and knowledge society" with an Asia IT\&C component program. Furthermore, several bilateral aid agencies have also placed ICT issues in their priority list.

\section{Production of ICT Materials for Farmers in the rural areas}

In order to reach the rural dwellers who are predominantly farmers and semi-literate, it is necessary to set up national infrastructure framework within each country to reach the grassroots using the existing ADP structure that has been put in place by the World Bank. The design of the infrastructure should take into cognizance the diverse networking requirements of these countries' landscape and the population density as well as the urban population density and spread.

The infrastructure in place should include the diverse media that will be required to deliver information to the users of agricultural information to feed the population. The ADP should serve as centers for relaying information to various zones apart from serving as data centre for repository, reproduction, distribution and administration of 
information material on agriculture. The different channels and formats should include textual materials, data, voice, graphic and multimedia demonstrations; to be distributed by broadcast (Radio and Television), captured and stored on video cassettes and CD-ROMS, audio and through computer mediated communications such as email and web-based multimedia materials sent on-line to students in remote locations.

The various ICT - facilitated activities enumerated above show how important these communication facilities are in any development process. Development communication entails a heavy reliance on communication strategies in an effort to achieve meaningful but accelerated development (Umar, 2003). ICTs facilitate this process with less difficulty and across distant areas. The computer technology is one of the basic ICTs which are in the heart of the development communication process made possible by these communication technologies. The various computer mediated communication processes already mention thus far, expedite one form of development process or the order.

\section{Synergizing ICTS and Traditional Media for Rural Development in Africa}

Nwabueze (2007), stressed that while utilizing the effective nature of the traditional media, ICTs could be used side by side to compliment the communication roles played by these indigenous agencies. The use of village meetings, age grade meetings, church forum and other platforms which create face to face communication setting between the sender (change/development agent) and the receiver (rural dwellers/community members) are conventional traditional media techniques of development.

On the other hand, ICTs such as the Direct Broadcast Satellite (DBS) facility, including tele-conference facilities could be used to bridge the gap between rural dwellers and change agents in urban areas. Where the development agent cannot get to certain rural areas physically, such facilities could be provided in strategic places like the village square or traditional ruler's palace, solely for development communication purposes.

Okoye (2003) contended that the general view that most rural dwellers are illiterate should not be brought to bear as a deterrent to the use of ICTs in the rural areas. He stressed that digital radio technology which is a type of ICT has the advantage of penetrating the most remote area and disseminating information to the rural poor, especially in their own local languages. Okoye further observed that research findings have established the potency of radio as the most popular and most credible source of news and entertainment in the rural areas of Africa.

Nwosu (1996) also identified opinion leaders to include "chiefs, priest, teachers and such relatively enlightened people in rural areas that development agents could use as direct sources of news, intermediary sources of news, interpreters and even pseudo or mini reporters that can initiate, write news and feature stories which we can improve upon for various purposes'. In the rural areas, opinion leaders are mostly enlightened or relatively literate persons dwelling among the people. The development agents could easily communicate with such people through internet facilities if made available in rural areas. This brings to the fore, the role of opinion leaders in rural development communication.

Shared facilities like tele-centres and info-kiosks could be established in rural communities by government. Considering the track record set by the internet, it has been observed that the same order of substantial success can be achieved in the area of development in rural Africa through its effective use. Mark Brown in his address "Challenges of Information and Communication Technology for Development", stressed that there is really no more critical question facing the developing countries today, than how to face up to the challenges and opportunities presented by the information revolution particularly, the phenomenon of the internet (Brown; 2000). Brown further contended that the internet is a two edge sword capable of leading the process of globalization with the potential of wounding those who failed to grasp quickly how to use it by leaving them further behind but providing unprecedented benefits for those with the courage and willingness to grasp its potentials to drive change. Richardson (1997) also observed that the internet brings new information resources and can open up new communication channels for rural communities. It presents a means for bridging the gap between development professionals and the rural people through the initiation of interaction and dialogue. In addition, the internet can foster new alliances and interpersonal networks together with literal and cross-sector links between organizations. Most importantly, it has the potential of supporting mechanisms that enable the articulation and sharing of information on needs and local knowledge.

The Food and Agricultural Organization (1997) has also asserted that enormous benefits await rural communities when communication improves between the non-governmental organizations, governmental services, private sector entities and educational institutes that support rural development. This the Food and Agricultural Organization further justified, by referring to the internet's capacity for interactive communication that engenders exchange of ideas. An integrated approach to expansion of internet services according to Richardson (1997), will promote the necessary but often neglected horizontal communication between the rural communities and the agencies linked to rural development.

However, estimates showed that the use of interest in Africa lags behind that of other regions (Oyeyinka and Lai, 2003). The regional distribution of internet users as at the first quarter of 2002 showed that out of the global figure of 580.78 million uses, Africa only supplied 6.31 million: about one percent of the world total. The global figure of internet users has grown since 2003 to 694 million people. The Internet Users Association stated that as at March 
31, 2007, there were 33,334,800 million internet users in Africa, out of the 933,448,292 million estimated populations for Africa. Nevertheless, if we consider the penetration rate as at 2007 which is just 3.6 percent, it becomes obvious that Africa is still behind in adaptation of the internet. For the internet to become a developmental tool in the nearest future, the governments of African countries must take deliberate steps to encourage its use.

Computer programmes could also be specifically developed for rural applications or for a rural based group (rural women, children, youths and so on). For instance, the International Women's Tribune Center (IWCT) developed a CD-Rom with the Nakaseke Women in Uganda using their language and simple point and click techniques which enabled illiterate women to use the internet (Zulu, 2004). Such strategies could be adopted in other African countries in bridging ICT gap between urban and rural dwellers as well as providing a relevant complement for the traditional media with respect to development communication with the rural dwellers (Nwabueze, 2007).

On the other hand, the nature of the traditional media gives them an edge over the modern mass media. Research evidence according to Nwabueze (2004), showed that with regards to diffusion of innovation, interpersonal channels of communication (such as the traditional media), are of greater importance than the modern mass media channels. This is apparently why the challenges facing today's policy makers, change agents and communication specialists in Africa, would be the need to understand clearly, what results the folk media could achieve for mobilization towards development purposes. What remains is for change agents to master the relevant strategies for utilizing the great opportunities provided by these traditional media in rural development. With ICTS playing complementary roles to the traditional media, rural dwellers will definitely be swayed to be part of the process that will better their lives and the society at large. Governments need to appreciate the relevance of these two broad communication channels in rural development as well as create the enabling environment for the synergistic process.

\section{The Challenges of Effective use of Traditional Media and ICTs in Rural Development in Africa}

Technological growth in the communication world is a source of threat to traditional communication agencies because rural dwellers no longer visit the village square regularly, due to the ravages of television sets, radio sets, satellite and newspapers. Those who can afford these communication gadgets now watch them in the comfort of their homes.

The inability of traditional communication to reach a large audience at the same time in contrast with the modern mass media is a source of concern for development communicators. Modern communication structures have the advantage of reaching millions of people simultaneously.

One of the basic challenges facing development communicators and other stakeholders in the development process is how to ensure the availability of ICT facilities such as: internet cyber cafes, video conferencing equipment, computer (laptops and desktops) as well as providing training opportunities on how to utilize these communication gadgets. This may seem expensive to countries in Africa but the advantages far outweigh the fears.

Providing the enabling environment for the ICTs to flourish is another challenge that must be addressed. Provision of regular power supply and security are very essential for certain ICT to be utilized. There is also the urgent need to train development communicators on how to effectively communicate with rural dwellers using the ICTs. This could be achieved by combining ICTs and traditional media in embarking on development -oriented communication, capable of mobilizing the rural poor for development activities.

While enumerating the potentials of cross fertilization of ideas between the rural communities and the development agencies, which is to engender sustainable rural development, the Food and Agricultural Organization stated some benefits of the information flow. These benefits include: increased efficiency in the use of development resources, less duplication of activities, reduction in the cost and global access to information. However the agency was quick to state that none of these benefits are guaranteed by the technological attributes of the ICTs. The challenge therefore, is for people to work together to make the most of a decentralized and accessible communication tool. From the above position, it is clear that ICTs can be communication tools for achieving sustainable rural development in Africa if decentralized and accessible. (Richardson, 1997).

\section{Conclusion}

The most critical problem facing the developing countries of the world particularly Africa, are the challenges and opportunities presented by the information revolution and particularly the phenomenon of the internet. These ICTs bring new information resources and can open up new communication channels for rural communities. It presents a means of bridging the gaps between change agents and the rural dwellers through the initiation of interaction and dialogue. Enormous benefits also await rural communities when communication improves between the non-governmental organizations, governmental services, private sector entities and educational institutes that support rural development.

However, it has been acknowledged that the global media channels (satellite, interest, etc) abound with their obvious advantages but it is also true that traditional media still retain a very useful place in development communication efforts in Africa. As Boafo (2006) rightly observed, traditional media are useful in development 
communication programmes because they serve as reliable channels of news, information gathering, processing and dissemination in many rural communities in Africa and often address local languages and cultural contexts which the community members can easily understand and identify with. Apart from providing horizontal communication approaches which stimulate discussions and analysis of issues, traditional media also sensitize and mobilize rural community dwellers for development activities.

For the ICTs and the traditional media to effectively play the role of influencing development by providing the people with the necessary information as well as teaching them specific things to do, there is the need for a synergy between both approaches.

\section{References}

Agbodike, C.C. (1992). Mass Mobilization and Rural Development in Nigeria: An Appraisal. In Olisa, M. and Obiukwu, J. I. (eds). Rural Development in Nigeria: Dynamics and Strategies. Awka; Mekslink Publishers.

Akpoveta, E. (2006). Communication as a Tool for Sustainable RuIral Development. nternational Journal of Communication, 4:205-216.

Akude, I. (1992). Traditional Agencies and Rural Development in Nigeria. In Olisa, M. and Obiakwu, J.I. (eds), Rural Development in Nigeria: Dynamics and Strategies. Awka; Mekslink Publishers.

Boafo, K.S.T. (2006). Participatory Development Communication: An African Perspective in Bessette, G. (ed). People, Land and Water. www.idre.ca/en/ev-98617-201-1-00-topic.html.

Brown, M M. (2000). The Challenges of Information and Communication Technology for Development. Tokyo: $\mathrm{UN}$.

Idode, J. B. (1989). Rural Development and Bureaucracy in Nigeria. Ikeja, Longman.

Mabogunje, A. (1978). Developing and Development. Ibadan; Ibadan University Press.

Muoghalu, L.N. (1992). Planning and Administration of Rural Development in Nigeria - The Missing link. In Olisa, M. and Obiukwu, J.I. (eds) Rural Development in Nigeria: Dynamics and Strategies; Awka; Mekslink Publishers.

National Orientation Agency. (2006). Attitudinal Change: Catalysts to National Development. Abuja; Reprographics Communications Ltd.

National Orientation Agency. (2006), Attitudinal Matters; The Role of Attitudes in Nigeria's Development. Ibadan; Spectrum Books Limited.

Nwabueze, C. (1995). The Role of Traditional Media in Rural Development: A Case Study of Ideato North L.G.A. of Imo State. Unpublished Project, Department of Mass Communication, U.N.N. Nsukka.

Nwabueze, C.D. and Nwabueze, C. (2007). ICTs, Traditional Media and Sustainable Rural Development: A Synergistic Approach. In Mojaye, E.M. et al, Ebenezer Soola Conference on Communication held in Ibadan.

Nwodu, G.C. (2003). Using Information and Communication Technologies (ICTs) to Check Electoral Fraud in Africa. A paper presented at the Biennal Conference of African Council for Communication Education (ACCE), held in Abuja, August $9^{\text {th }}-13^{\text {th }}$.

Nwosu, I.E. (1990). An Overview of the Relationship between Communication and Rural Development. In Nwosu, I.E. (ed), Mass Communication and National Development: Perspectives on the Communication Environment of Development in Nigeria. Aba; Frontier Publishers Ltd.

Ochonogor, .CI. (2005). The Mass Media as Agents of Development and Social Change in Africa. Abraka Humanities Review: A Journal of the Faculty of Arts, 1(1): 123-137.

Okoye, I. (2003). The Use of Local and Foreign Radio by the Nigerian Elite. A Study of two Low Density Residence Areas of Lagos Metropolis. The Nigeria Journal of Communications, 2(1-2): 124-132.

Oziwele, P.E. (2007). The Relevance of Traditional Communication in the Face of Modernity. In Mojaye, E.M. et al, Ebenezer Soola Conference on Communication held in Ibadan.

Richardson, D. (1997). The Interest and Rural and Agricultural Development: An Integrated Approach. Rome: FAO.

Umar, M.M. (2003). Significance of Participatory Communication in Non-Formal Political Education in Northern Zaria: The Nigerian Journal of Communication, 2(1-2): 1-7.

Yarhere, D. (2007). Communication and Modera ICTS: Implication for Agricultural information Dissemination in Nigeria. In Mojaye, E.M et al (eds). Ebenezer Soola Conference on Communication: Proceedings.

Zulu, B. (2004). Bridging the Rural Digital Divide in Africa. Daily Champion Newspapers, Wednesday, August 11. 